Journal of Fisheries International 5 (2): 31-35, 2010

ISSN: $1817-3381$

(C) Medwell Journals, 2010

\title{
Effect of Stocking Density and Bacterial Load on the Commercial Production of Pearl Oyster Pinctada fucata (Gould) Larvae
}

\author{
S.K. Subhash and A.P. Lipton \\ Marine Biotechnology Laboratory, Vizhinjam Research Centre of Central Marine, \\ Fisheries Research Institute, Vizhinjam, 695521, Kerala, India
}

\begin{abstract}
Commercialization of pearl culture requires large scale hatchery production of larvae. The survival of larvae depends on stocking density, environmental factors, diets and diseases. The results of experiments using 4 stocking densities at the rate of $100,1000,2000$ and 3000 larvae $\mathrm{L}^{-1}$ of filtered sea water indicated highest survival of 15.8 and $10.5 \%$ in the low stocking densities followed by 1.4 and $0.34 \%$, respectively in other 2 stocking densities at an ambient temperature of $28.6 \pm 0.4^{\circ} \mathrm{C}$. Although, the larvae were fed with Isochrysis galbana at the recommended cell densities, a positive correlation between increased bacterial load and pearl oyster larval survival was recorded in all the stocking densities. Eventhough, total number of spat produced in 100 and 1000 larvae $\mathrm{L}^{-1}$ stocking density was more or less similar and considering the management strategies including man power, cost of production of microalgal culture and infrastructure facilities such as availability of tanks and space in an established hatchery the stocking density of 1000 larvae $\mathrm{L}^{-1}$ will be optimum for commercial hatchery production of pearl oyster larvae.
\end{abstract}

Key words: Pearl oyster, spat, bacterial load, growth, Vibrio, India

\section{INTRODUCTION}

During the artificial rearing of the bivalve larvae, many different factors affect their growth and survival for example egg quality, food type and quantity, temperature, salinity and water quality (Gosling, 2003). Another important factor is the stocking density. This effect has been little studied, even though it is most important in the artificial rearing of mollusc larvae as it determines the production in the hatchery. For pearl oysters, larval rearing densities for C. virginica vary from 10 larvae $\mathrm{mL}^{-1}$ (Newkirk et al., 1977) to 5-8 larvae $\mathrm{mL}^{-1}$ (Mallet and Haley, 1983).

For the hard clam, M. mercenaria, Hilbish et al. (1993) reported initial stocking densities of 10 larvae $\mathrm{mL}^{-1}$. Larval rearing densities for Pinctada maxima vary from $1-8 \mathrm{~mL}^{-1}$ (Rose and Baker, 1994). The optimal larval density for Pinctada fucata has not been determined: however, they are generally reared at a density of 3-28 larvae $\mathrm{mL}^{-1}$ (Alagarswami et al., 1983). A major problem with hatchery culture of $P$. fucata is low survival (generally $<5.0 \%$ ) during larval culture (Subhash et al., 2003; Dharmaraj, 2005; Subhash, 2009). Larval mortalities occurring in molluscan hatcheries have often been associated with bacterial contamination and more specifically with vibrios (Tubiash et al., 1965;
Lipton et al., 2003; Leon et al., 2005; Hasegawa et al., 2008). Sandlund et al. (2006) reported that opportunistic bacteria cause almost $100 \%$ mortality during larval stages of the bivalve Pecten maximus. The findings of Subhash (2009) indicated that hatchery production of Pinctada fucata was seriously affected by massive larval mortalities caused by Vibrio sp. This indicates that efficient large scale hatchery production of $P$. fucata requires further research to investigate the specific culture requirements of this species. Very little information is available on the effect of stocking density and bacterial load on the survival and settlement of pearl oyster larvae. In this study, we consider the combined effect of stocking density and bacterial load on the commercial production of $P$. fucata seed.

\section{MATERIALS AND METHODS}

Spawning and larval rearing: The experiments were conducted at the pearl oyster hatchery of Mandapam Regional Centre of Central Marine Fisheries Research Institute, Mandapam, Tamilnadu. Oysters collected from the Gulf of Mannar and stocked in dark interior Fiberglass Reinforced Plastic (FRP) tanks were induced to spawn by increasing the water temperature from $27.8-33.6^{\circ} \mathrm{C}$. The fertilised eggs were collected in $30 \mu \mathrm{M}$

Corresponding Author: S.K. Subhash, Marine Biotechnology Laboratory, Vizhinjam Research Centre of Central Marine, Fisheries Research Institute, Vizhinjam, 695521, Kerala, India 
sieve and released in to freshly filtered sea water in FRP tanks. Five days old larvae were used for the experiments.

Experimental arrangements: Larvae were stocked in FRP tanks of 1.5 ton capacity containing $1000 \mathrm{~L}$ of filtered sea water $(0.2 \mu)$ at 4 stocking densities: 3000, 2000, 1000 and 100 larvae $\mathrm{L}^{-1}$ of filtered seawater with 3 replicates for each stocking density. Water exchange was done on alternate days. Micro algae, Isochrysis galbana was given as feed as per the feeding protocol (Alagarswami et al., 1983).

Hydrological parameters and estimation of bacterial load: Hydrological parameters such as temperature and $\mathrm{pH}$ were monitored daily. Dissolved oxygen and salinity were monitored on alternate days and once in a week respectively (APHA, 1989). The bacterial load of the intake water as well as water from the 4 experimental tanks was determined by Total Plate Count (TPC). Water samples were collected aseptically prior to water exchange on alternate days and plated on nutrient agar plates supplemented with $2.5 \% \mathrm{NaCl}$ using the pour plate method (Collins et al., 2001).

Estimation of larval population: Larval population of $P$. fucata was estimated immediately after exchanging water. The larvae were collected in $100 \mathrm{~L}$ FRP tank by using suitable mesh ranging from $20-150 \mu$ (i.e., from D shape Veliger to Plantigrade stage). The water in the beaker was mixed and sub samples $(1 \mathrm{~mL})$ were taken in an embryo cup and counted at $100 \mathrm{X}$ magnification. The average value obtained by repeated sampling was multiplied with $1,00,000$ to get the total larval densities in $100 \mathrm{~L}$ (Alagarswami et al., 1983). All the statistical analysis was performed by Microsoft Statistica 1.4 software.

\section{RESULTS AND DISCUSSION}

Hydrological parameters: No significant (ANOVA, $\mathrm{p}>0.001$ ) difference in hydrological conditions were noted between the different stocking density groups during the experimental period. The temperature ( $28.6 \pm 0.3$ to $\left.29.1 \pm 0.4^{\circ} \mathrm{C}\right), \mathrm{pH} \quad(8.31 \pm 0.02$ to $8.32 \pm 0.02)$, dissolved oxygen $\left(4.41 \pm 0.14\right.$ to $\left.4.44 \pm 0.14 \mathrm{mg} \mathrm{L}^{-1}\right)$ and salinity $29.5 \pm 0.05$ to $30.5 \pm 1.5 \mathrm{ppt}$ ) were within the optimal ranges for larval growth.

Bacterial load and survival of pearl oyster larvae: The bacterial load in the filtered water received in the rearing tank ranged from $1.0-9.0 \times 10^{1} \mathrm{cfu} \mathrm{mL}^{-1}$. High larval mortality of $21.0,25.0,26.0$ and $10.0 \%$ were noted on days $9,13,15$ and 17 , respectively in the stocking density of 3000 larvae $L^{-1}$. In the stocking densities of 2000 and 1000 larvae $\mathrm{L}^{-1}$ larval mortality was noted on day 9,13 and 15 th. In the low stocking density of 100 larvae $\mathrm{L}^{-1}$ high larval mortality of 13.6 and $20.6 \%$ was noted on day 13 and 15 th.

The bacterial load ranged from $1.0 \times 10^{2}$ to $8.3 \times 10^{3}$, $1.0 \times 10^{2}$ to $6.1 \times 10^{3}, 1.0 \times 10^{2}$ to $3.0 \times 10^{3}$ and $1.0 \times 10^{2}$ to $2.4 \times 10^{3}$ in the 4 stocking densities of $3000,2000,1000$ and 100 larvae $\mathrm{L}^{-1}$, respectively. Bacterial load at different stocking densities and mortality of Pinctada fucata larvae during the experiment were shown in Table 1.

Survival of larvae and spat production in the four stocking densities: Very low spat production of 0.35 and $1.4 \%$ were obtained in the higher stocking density of 3000 and 2000 larvae $\mathrm{L}^{-1}$. In the stocking density of 1000 larvae $\mathrm{L}^{-1}, 10.5 \%$ spat production was obtained and in the low stocking density of 100 larvae $\mathrm{L}^{-1}$, it was $15.8 \%$ (Fig. 1). The cumulative mortality and bacterial load during the study period is shown in Table 2 .

Hatchery production of pearl oysters is relatively new. Reflecting this and the lack of knowledge of culture requirements, a number of studies have reported relatively poor survival of pearl oyster larvae during hatchery culture. Larval mortalities occurring in molluscan hatcheries have often been associated with bacterial contamination favored by rearing conditions such as high temperature, excess food and high larval density. Two types of infestation have been described. The first corresponds due to the specific development of pathogenic bacteria such as Pseudomonas (Brown, 1974), Alteromonas (Garland et al., 1983) and Vibrios (Leon et al., 2005; Sandlund et al., 2006; Hasegawa et al., 2008; Subhash, 2009). The second is due to the contamination of sea water by heterotrophic bacteria which induces larval mortalities when their density is high in larval rearing water (Lipton et al., 2003; Subhash et al., 2003, 2007).

This manifested in to high mortality and poor spat settlement in the present study in which 99.65 and $98.6 \%$ of mortality was recorded with a high average bacterial load of $2.2 \times 10^{3}$ and $1.7 \times 10^{3} \mathrm{cfu} \mathrm{mL}^{-1}$ at high stocking density of 3000 and 2000 larvae $\mathrm{L}^{-1}$. On the other hand, a low mean bacterial load of $6.7 \times 10^{2} \mathrm{cfu} \mathrm{mL}^{-1}$ with comparatively low mortality of $84.2 \%$ was observed in the lowest stocking of 100 larvae $\mathrm{L}^{-1}$. Interestingly a low mean bacterial load of $8.9 \times 10^{2} \mathrm{cfu} \mathrm{mL}^{-1}$ with a mortality of 
Table 1: Bacterial load and mortality of Pinctada fucata at different stocking densities

\begin{tabular}{|c|c|c|c|c|c|c|c|c|}
\hline \multirow{3}{*}{$\begin{array}{l}\text { No. of } \\
\text { days }\end{array}$} & \multicolumn{8}{|c|}{ No. of larvae $\mathrm{L}^{-1}$} \\
\hline & \multicolumn{2}{|l|}{3000} & \multicolumn{2}{|l|}{2000} & \multicolumn{2}{|l|}{1000} & \multicolumn{2}{|l|}{100} \\
\hline & Mortality & Bacterial load & Mortality & Bacterial load & Mortality & Bacterial load & Mortality & Bacterial load \\
\hline 7 & 6.40 & $2.2 \times 10^{2}$ & 4.4 & $1.2 \times 10^{2}$ & 0.0 & $1.0 \times 10^{2}$ & 0.0 & $1.0 \times 10^{2}$ \\
\hline 9 & 21.00 & $2.7 \times 10^{3}$ & 20.0 & $2.3 \times 10^{3}$ & 17.8 & $1.1 \times 10^{3}$ & 6.4 & $1.4 \times 10^{2}$ \\
\hline 11 & 8.30 & $9.0 \times 10^{2}$ & 7.3 & $1.8 \times 10^{2}$ & 6.8 & $1.6 \times 10^{2}$ & 6.8 & $1.5 \times 10^{2}$ \\
\hline 13 & 25.00 & $7.9 \times 10^{3}$ & 23.5 & $6.1 \times 10^{3}$ & 19.4 & $3.0 \times 10^{3}$ & 13.6 & $1.9 \times 10^{3}$ \\
\hline 15 & 26.00 & $8.3 \times 10^{3}$ & 23.0 & $6.0 \times 10^{3}$ & 22.8 & $2.7 \times 10^{3}$ & 20.6 & $2.4 \times 10^{3}$ \\
\hline 17 & 10.00 & $1.0 \times 10^{3}$ & 4.0 & $3.6 \times 10^{2}$ & 6.3 & $5.8 \times 10^{2}$ & 6.2 & $4.0 \times 10^{2}$ \\
\hline 19 & 0.95 & $2.5 \times 10^{2}$ & 8.0 & $7.0 \times 10^{2}$ & 7.0 & $5.0 \times 10^{2}$ & 7.3 & $4.0 \times 10^{2}$ \\
\hline 21 & 1.00 & $2.0 \times 10^{2}$ & 5.0 & $6.0 \times 10^{2}$ & 5.9 & $5.0 \times 10^{2}$ & 7.6 & $5.0 \times 10^{2}$ \\
\hline 23 & 0.50 & $2.0 \times 10^{2}$ & 2.8 & $4.0 \times 10^{2}$ & 2.7 & $3.0 \times 10^{2}$ & 8.8 & $4.0 \times 10^{2}$ \\
\hline 25 & 0.50 & $1.0 \times 10^{2}$ & 0.6 & $1.0 \times 10^{2}$ & 0.8 & $1.0 \times 10^{2}$ & 6.9 & $3.0 \times 10^{2}$ \\
\hline
\end{tabular}

Table 2: Cumulative mortality and bacterial load during larval rearing of Pinctada fucata

\begin{tabular}{lcc}
\hline Larvae $\mathrm{L}^{-1}$ & Total mortality (\%) & Bacterial load (cfu mL $\left.{ }^{-1}\right)$ \\
\hline 3000 & $99.65^{\mathrm{a}}$ & $2.2 \times 10^{3 \mathrm{a}}$ \\
2000 & $98.60^{\mathrm{a}}$ & $1.7 \times 10^{3 \mathrm{a}}$ \\
1000 & $89.50^{\mathrm{b}}$ & $8.9 \times 10^{2 \mathrm{~b}}$ \\
100 & $84.20^{\mathrm{b}}$ & $6.7 \times 10^{2 \mathrm{~b}}$ \\
\hline
\end{tabular}

Values sharing a common superscript are not significantly different $(\mathrm{p}<0.05)$

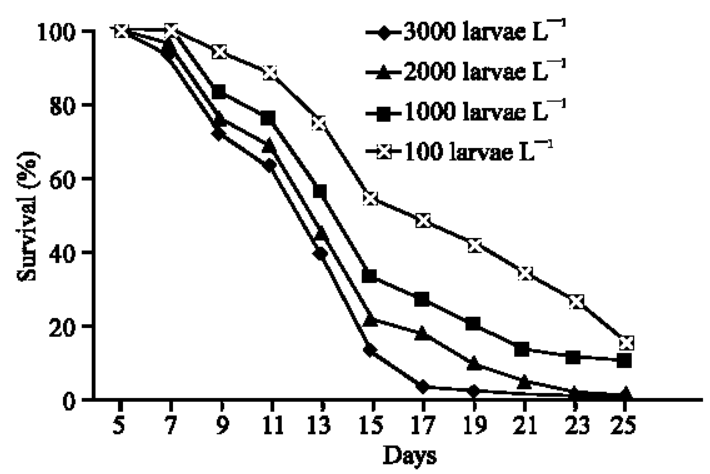

Fig. 1: Survival of larvae in different stocking densities

$89.5 \%$ was noted in the stocking of 1000 larvae $\mathrm{L}^{-1}$ (Table 2). Although, the hydrological parameters such as temperature, $\mathrm{pH}$, salinity and dissolved oxygen content were almost similar in the 4 stocking densities; the bacterial load was higher in the high stocking density. Moreover, high bacterial load was found in the culture tank water during high larval mortalities in all the stocking densities showing a positive correlation between larval mortality and bacterial load.

High larval mortality was found on 9, 13, 15 and 17 th day in the stocking density of 3000 larvae $\mathrm{L}^{-1}$. High bacterial load of $2.7 \times 10^{3}, 7.9 \times 10^{3}, 8.3 \times 10^{3}$ and $1.0 \times 10^{3} \mathrm{cfu} \mathrm{mL} \mathrm{m}^{-1}$ was noted in the culture tank water when mortality was $21.0,25.0,26.0$ and $10.0 \%$ (Table 2). The results showed a positive correlation between high larval mortality with increasing bacteria load in culture tank water $(r=0.8779)$. In the stocking of 2000 larvae $L^{-1}$ on 9 ,
13 and 15 th day high mortalities was noted. Here also the total viable count of bacteria was increasing in the culture tank water during larval mortality $(\mathrm{r}=0.9940)$. High bacterial load of $2.3 \times 10^{3}, 6.1 \times 10^{3}$ and $6.0 \times 10^{3} \mathrm{cfu} \mathrm{mL}^{-1}$ was noted when mortality was $20.0,23.5$ and $23.0 \%$. In the density of 1000 larvae $\mathrm{L}^{-1}$, high larval mortality of 17.8 , 19.4 and $22.8 \%$ was found on 9,13 and 15 th day with a high bacterial load of $1.1 \times 10^{3}, 3.0 \times 10^{3}$ and $2.7 \times 10^{3}$ showing a positive correlation between bacterial load in culture tank water and larval mortality $(r=0.6403)$. High larval mortality of 13.6 and $20.6 \%$ was noted on 13 and 15 th day with a high bacterial load of $1.9 \times 10^{3}$ and $2.4 \times 10^{3}$ even in the very low stocking density of 100 larvae $\mathrm{L}^{-1}$ confirming the positive correlation of bacterial load and larval mortality $(r=1.0)$ in the pearl oyster hatchery.

Similar study by Subhash et al. (2007) also revealed that the total bacterial load in the culture tank water was found to increase in the hatcheries of Pinctada fucata during disease out breaks resulting in heavy larval mortality. A comparable trend of high bacterial load associated with larval mortality was noted 4 times (day 9 , 13,15 and 17 th) in the dense stocking system of 3000 larvae $\mathrm{L}^{-1}$ during the course of the experiment. The combination of high larval densities, debris from dead larvae and high load of organic matter due to addition of live food could have stimulated the selection and growth of opportunistic bacteria in larval tanks (Skjermo and Vadstein, 1999; Torkildsen et al., 2005; Hernandez and Martinez, 2005). Moreover, in the low stocking density of 100 larvae $\mathrm{L}^{-1}$ also such a trend of decreased larval population associated with high bacterial load was noted 2 times (day 13 and 15th). Thus, bacterial load could be the important (key) factor determining the survival and spat settlement of pearl oyster larvae.

Poor spat setting of 0.35 and $1.4 \%$ were observed in higher stocking densities of 3000 and 2000 larvae $\mathrm{L}^{-1}$. Reported studies showed that there is an inverse relationship between larval survival and larval density 
(Ibarra et al., 1997; Doroudi and Southgate, 2000). Krishnan and Alagarswami (2003) reported a low survival of $1.8 \%$ in Pinctada fucata hatchery at a stocking density of 3000 larvae $\mathrm{L}^{-1}$. Recently, Subhash et al. (2007) also reported a low survival of $0.82 \%$ in the high stocking density of 5000 larvae $\mathrm{L}^{-1}$ in the Pinctada fucata hatchery.

On the other hand at the stocking density of 1000 larvae $L^{-1}$, the survival was $10.5 \%$ and out of 10 lakh larvae stocked an average of $1,05,000$ spat were produced. However in the lowest stocking density of 100 larvae $\mathrm{L}^{-1}$, the survival was $15.8 \%$ and out of 1 lakh larvae stocked an average of 15,800 spat were produced. Comparing the total number of spat settled in 1000 and 100 larvae $\mathrm{L}^{-1}$ stocking densities and considering the management strategies including man power, cost of production of microalgal culture and infrastructure facilities such as availability of tanks and space in an established hatchery the stocking density of 1000 larvae $\mathrm{L}^{-1}$ will be optimum for commercial hatchery production of pearl oyster larvae.

\section{ACKNOWLEDGEMENT}

The researchers are thankful to the director of CMFRI for the facilities and encouragement.

\section{REFERENCES}

APHA, 1989. Standard Methods for the Examination of Water and Waste Water. 17th Edn., American Public Health Association, Washington, DC.

Alagarswami, K., S. Dharmaraj, T.S, Velayudhan, A. Chellam, A.C.C. Victor and A.D. Gandhi, 1983. Larval rearing and production of spat of pearl oyster Pinctada fucata (Gould). Aquaculture, 34: 287-301.

Brown, C., 1974. A pigment-producing pseudomonad which discolors culture containers of embryos of a bivalve mollusc. Chesapeake Sci., 15: 17-21.

Collins, C.H., P.M. Lyne, and J.M. Grange, 2001 . Collins and Lyne's Microbiological Methods. 7th Edn., Arnold London, pp: 493.

Dharmaraj, S., 2005. Hatchery Production of Pearl Oyster Seeds. In: Recent Advances in Mussel and Edible Oyster Farming and Marine Pearl Production-Winter School Technical Notes, Modayil, M.J. (Ed.). Central Marine Fisheries Research Institute, Cochin, pp: $52-56$.

Doroudi, M.S. and P.C. Southgate, 2000. The influence of algal ration and larval density on growth and survival of blacklip pearl oyster Pinctada margaritifera L. larvae. Aquacult. Res., 31: 621-626.
Garland, C.D., G.V. Nash, C.E. Sumner and T.A. McMeekin, 1983. Bacterial pathogens of oyster larvae (Crassostrea gigas) in a Tasmanian hatchery. Aust. J. Mar. Freshwa. Res., 34: 483-487.

Gosling, E.M., 2003. Bivalve Molluscs-Biology, Ecology and Culture. Iowa state press, State Avenue, Ames, Iowa, USA, pp: 443.

Hasegawa, H., E.J. Lind, M.A. Boin and C.C. Hase, 2008. The extracellular metalloprotease of Vibrio tubiashii is a major virulence factor for pacific oyster Crassostrea gigas larvae. Appl. Environ. Microbiol., 74: 4101-4110.

Hernandez, J.C.S. and A.N.M. Martinez, 2005. Sources of Vibrio bacteria in mollusk hatcheries and control methods: A case study. Aquacult. Res., 36: 1611-1618.

Hilbish, T.J., E.P. Winn and P.D. Rawson, 1993. Genetic variation and covariation during larval and juvenile growth in Mercenaria mercenaria. Mar.Biol., 115: 97-104.

Ibarra, A.M., J.L. Ramirez, and G.A. Garcia, 1997. Stocking density effects on larval growth and survival of two catarina scallop, Argopecten ventricosus (=circularis) (Sowerby 11, 1842) populations. Aquacult. Res., 28: 443-451.

Krishnan, A. and K. Alagarswami, 2003. Spatial and feed requirements of larvae of the Indian pearl oyster Pinctada fucata (Gould). First Indian Pearl Congress and Exposition, Feb: 5-8 Central Marine Fisheries Research Institute, pp: 47-49.

Leon, J.G., L. Villamil, M.L. Lemos, B. Novoa and A. Figueras, 2005. Isolation of Vibrio splendidus from aquacultured carpet shell clam (Ruditapes decussates) larvae associated with mass mortalities. Appl. Environ. Microbiol., 71: 98-104.

Lipton, A.P., S.K. Subhash, R.P. Raj and A.A. Rani, 2003. Influence of environmental factors and microbial load on the spat settlement of pearl oyster, Pinctada fucata. Proceedings of the First Indian Pearl Congress and Exposition, Feb 5-8, Central Marine Fisheries Research Institute, Cochin, pp: 52-54.

Mallet, A.L. and L.E. Haley, 1983. Growth and survival of pure population matings and crosses in the Atlantic oyster. Can. J. Fish. Aquatic. Sci., 40: 948-954.

Newkirk, G.F., D.L. Waugh and L.E. Haley, 1977. Genetics of larval tolerance to reduced salinities in two populations of oysters, Crassostrea virginica. J. Fisheries. Res. Board. Canada, 34: 383-387.

Rose, R.A. and S.B. Baker, 1994. Larval and spat culture of the Western Australian silver or gold lip pearl oyster, Pinctada maxima Jameson (Mollusca: Pteriidae). Aquaculture, 126: 35-50. 
Sandlund, N., L. Torkildsen, T. Magnesen, S. Mortensen and O. Bergh, 2006. Immunohistochemistry of great scallop Pecten maximus larvae experimentally challenged with pathogenic bacteria. Dis. Aquat. Org., 69: 163-173.

Skjermo, J. and O. Vadstein, 1999. Techniques for microbial control in the intensive rearing of marine larvae. Aquacult., 177: 333-343.

Subhash, S.K., 2009. Studies on disease resistance among pearl oyster Pinctada fucata (Gould) larvae and spat influenced by probiotic bacteria. Ph.D. Thesis, Manonmaniam Sundaranar University, Tirunelveli, Tamil Nadu, India.

Subhash, S.K., A.P. Lipton and R.P. Raj, 2007. Stocking density dependent bacterial load and its influence on the production of pearl oyster Pinctada fucata (Gould) seed, Indian. J. Anim. Sci., 77: 420-423.
Subhash, S.K., A.P. Lipton and R.P. Raj, 2003. Influence of stocking density and microbial load on the survival and settelment pattern of the larvae of pearl oyster, Pinctada fucata (Gould). Proceedings of the 1st International Conference on Disease Management for Sustainable Fisheries, pp: 52-54. http://www.researchintouse.com/nrk/RIUinfo/outp uts/R8119_FTR_Appendix.pdf.

Torkildsen, L., C. Lambert, A. Nylund, T. Magnesen and O. Bergh, 2005. Bacteria associated with early life stages of the great scallop, Pecten maximus: Impact on larval survival. Aquacult. Int., 13: 575-592.

Tubiash, H.S., P.E. Chanley andE. Leifson, 1965. Bacillary necrosis a disease of larval and juvenile bivalve mollusks. J. Bacteriol., 90: 1036-1044. 